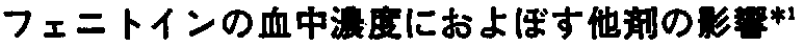

\author{
海野勝男，須藤一郎，富野昭子，福井了三，官田良子*2a \\ 矢幅義男，小畑信彦，肥田野文夫*2b \\ 秋田大学医学部付䦸病院荣都部*2s \\ 秋田大学医学部付用病院神経精神科*81
}

\section{Influence of Various Drugs on Serum Level of Phenytoin*1}

\author{
Katsuo UnNo, IchiRo Suto, AKIKo TOMINo, Ryozo FukUi, \\ RYOKO MIYATA*2a, YOSHIO YAHABA, NOBUHIKo OBATA, and \\ FUMIO HIDANO*2b \\ Pharmacy, Akita University Hospital*2a \\ Department of Neuropsychiatry, Akita University School of Medicine*zb
}

(Received January 21, 1980)

Serum level of phenytoin (DPH) in 204 patients receiving an oral anticonvulsant was determined by EMIT AED method. DPH level was significantly higher $(P<0.05)$ in patients given DPH and 2 or more other drugs than in those on DPH only or on DPH and one other agent. In 127 patients given DPH and 2 or more other drugs, influence of phenobarbital, primidone, carbamazepine and acetazolamide on serum DPH level was studied. The influence in the group was not significantly different from the group given phenytoin only. The DPH level was lowered significantly $(P<0.05)$ in the group subjected to the combination therapy of DPH with clonazepam. Then, serum level of DPH bulk powder marketed from manufacturer A was compared with that of bulk powder of manufacturer B, both products given to the same patients in the same dosage. The serum level of DPH-B, as a result, was 3 times $(\mathrm{P}<0.01)$ as high as that of DPH-A.

\section{は じめた}

前報1)において当院精神科ならびに小児科のてんか ん患者81例を対象として, Phenytoin (以下 DPH と略 す）の血中港度を EMIT と GLC を用いて比較娭討し， 相阙係数 $\mathrm{r}=0.97$ ときわめてよく, とくに EMIT 法は 試料が少量で斉み，しかる短時間で測定できる利点があ ること、および溶血などによる影售す少ないことを報告 した.

*1本報を抗てんかん薬の血中湍度に関する研究（第 2 報）とする．日本薬学会第 99 年会（札聭，1979 年8月）で発表.

*8a,b 秋田市本道 1 丁目1-1; 1-1, Hondo 1-chome, Akita-shi, 010 Japan
今回さらに精神科患者 107 名（204 検体）を対象とし $\tau$, DPHの血中搌度を測定し, 併用頻度の高い Phenobarbital (以下 PBと咯す), Primidone (以下 PM と略 す), Carbamazepine (以下 CBZ と略す), Acetazolamide (以下 ACA と略す), Sultiame (以下 SUL と略 ち), Clonazepam (以下 CZP と咯す) との相互作用の

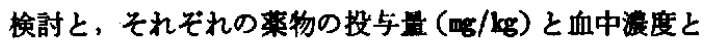
の咸係について検討したので報告する.なお市貶 DPH 原末 2 製派に拈ける bioavailability の比較む行ったの で報告する。

$$
\text { 対争方法 }
$$

\section{対保症例}

秋田大学医学部付属病院精神科抗てんかん菜服用患者 
107名（男子は45名, 女子は61名）計204検体を対象とし た. 年龄は13〜19歳 31名, 20〜29歳 33名, 30〜39歳 27 名, 40〜49才 12名で 50歳以上が 4 名であった. DPH 血 中濃度の測定は前報の EMIT 法に準じて測定を行った。

\section{服薬状況}

204 検体すべて DPH を服用しており，DPH の単独 使用は26検体であった， 2 種併用例は51検体， 3 種以上: の多剂併用例は 127検体であった。これら併用薬の中で は CBZ が最も多く使用されており，128検体 (72\%)，つ いで PB が 94検体 (52\%)，PM 70検体（39\%）であ り，その他はほかの抗てんかん薬，たとえば ACA，S UL, Phenetride が併用されており，その維み合わせ数 は60種類にもみられた。その中での主な俳用例を挙げる ると, 次のごとくである.
1) $\mathrm{DPH}$ と $\mathrm{CBZ}$

24 検体一 2 種併用

2) $\mathrm{DPH}$ と $\mathrm{PB}$ 14検体

3) $\mathrm{DPH}$ と $\mathrm{PB}$ と $\mathrm{PM}$ と $\mathrm{CBZ} 14$ 検体— 4 種併用

4) $\mathrm{DPH} と \mathrm{PM}$

11 検体一 2 種併用

5） $\mathrm{DPH}$ とPBとCBZとACA 11検体— 4 種併用

6) $\mathrm{DPH}$ と $\mathrm{PB}$ と $\mathrm{PM}$ と $\mathrm{CBZ}$ と $\mathrm{ACA} 9$ 検体一 5 種併用

7) $\mathrm{DPH}$ と $\mathrm{PB}$ と $\mathrm{CBZ} 9$ 検体一 3 種併用 そのほか53種の組み合わせである。

結 果

\section{DPH 単独時の DPH 血中濝度}

Fig.1-1 は DPH 単独27例の投与量 $(\mathrm{mg} / \mathrm{kg}$ ) と血中濃 度 $(\mu \mathrm{g} / \mathrm{ml})$ の関係を示したものである. 投与量に比べ血 中レベルが低く, 相関性 $(r=0.49)$ はあまりよくない.

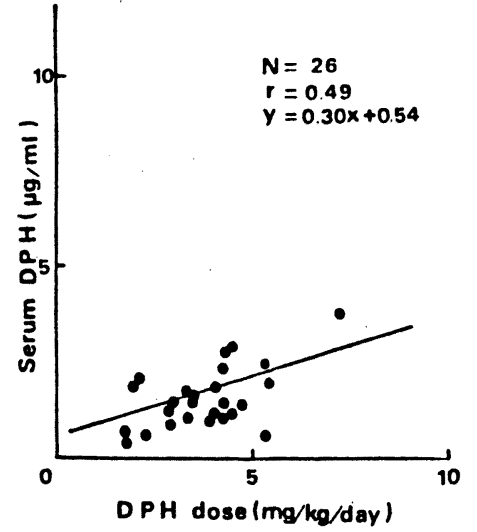

Fig. 1-1. Serum Levels of DPH Alone

\section{DPH 2 程併用時の DPH 血中絔度}

Fig.1-2 は DPH 2種併用の 51例，DPHとCBZ が 24 例, $\mathrm{DPH}$ と $\mathrm{PB}$ が 14 例, $\mathrm{DPH}$ と $\mathrm{PM}$ が 11例, $\mathrm{DPH}$ と

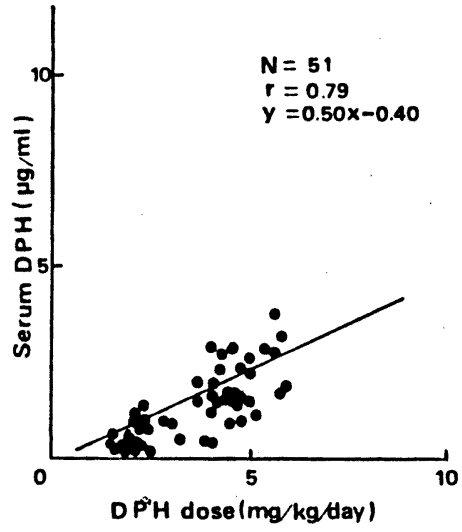

Fig.1-2. Serum Levels of DPH with Two-drug Combinations Treatment

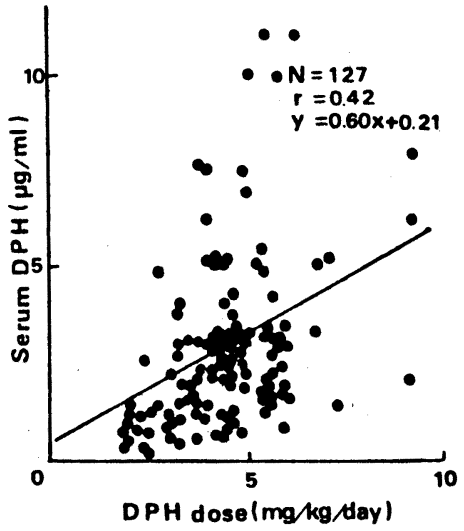

Fig. 1-3. Serum Levels of DPH with Multiple Drugs Treatment

Table 1. Serum DPH Levels Data

\begin{tabular}{l|c|c|c|c|c}
\hline G roups & $N$ & $D(m g / k g$ day & $L(\mu \mathrm{g} / \mathrm{ml})$ & $\begin{array}{c}\text { Correlation } \\
\text { coefficient }\end{array}$ & S lope \\
\cline { 3 - 6 } & $\bar{X} \pm S D$ & $\bar{X} \pm S D$ & 0.49 & 0.30 \\
D PH alone 26 & $3.8 \pm 1.3$ & $1.7 \pm 0.8$ & 0.79 & 0.50 \\
with two drugs 51 & $3.6 \pm 1.5$ & $1.4 \pm 0.9$ & 0.79 & 0.60 \\
\hline
\end{tabular}




\section{DPH 亡多剂併用時における DPH 血中憼度}

Fig.1-3 に示すように 3 種以上の DPH 多剤併用例に 扣ける DPH の血中濃度を示したもので，非常にバラッ キが多いが，Fig.1-1，1-2 に比べ高值を示す症例が多 くなっている.

以上 DPH 単独, 2 種併用例, 多剂併用例飞括ける DPHの投与量と血中濃度の関係を Table 1 飞示した.

\section{PB と PMの併用および非併用時における DPH}

\section{血中灌度}

DPHの多剤併用 127例において，PB併用時における

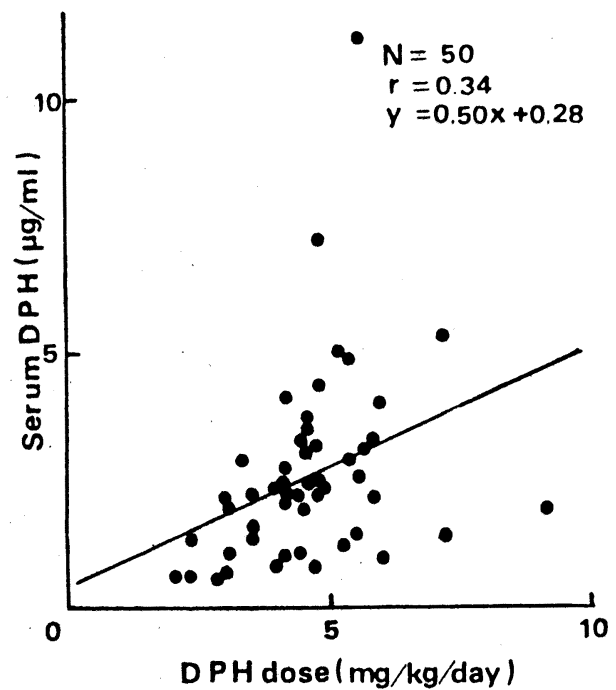

Fig. 2-1. Serum Levels of DPH with PB Treatment

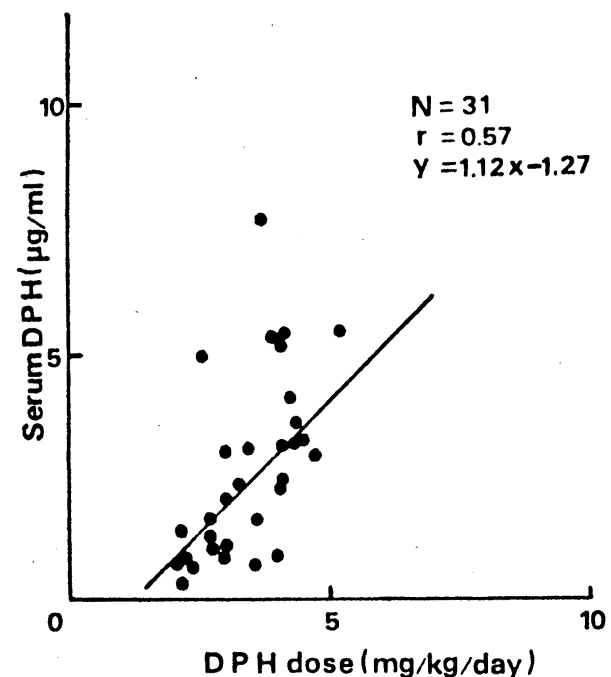

Fig. 2-3. Serum Levels of DPH with PB and PM Treatment
DPH の投与量と血中蕽度の関係を Fig. 2-1 に示した。 血中濃度 $5 \mu \mathrm{g} / \mathrm{ml}$ 以上のものが 3 例 $(6 \%)$ と少なく, 相関係数 $\mathrm{r}=0.34$ と低い. また Fig. 2-2 は DPH と PM との併用時に打ける DPH の血中濃度を示したもので PB 併用例に比べ高い血中濃度を示している.

Fig. 2-3 はPB とPM の同時併用例を示したもので, $\mathrm{DPH}$ の投与量が $5 \mathrm{mg} / \mathrm{kg}$ 以上の症例が少ないが，回帰直 線が $\mathrm{Y}=1.12 \mathrm{X}-1.27$ と高值を示した。つぎに $\mathrm{PB}$ お よび PM を併用していない18 例について検討したもの をFig. 2-4 に示したが， DPH 血中濃度が $10 \mu \mathrm{g} / \mathrm{ml}$ 以上

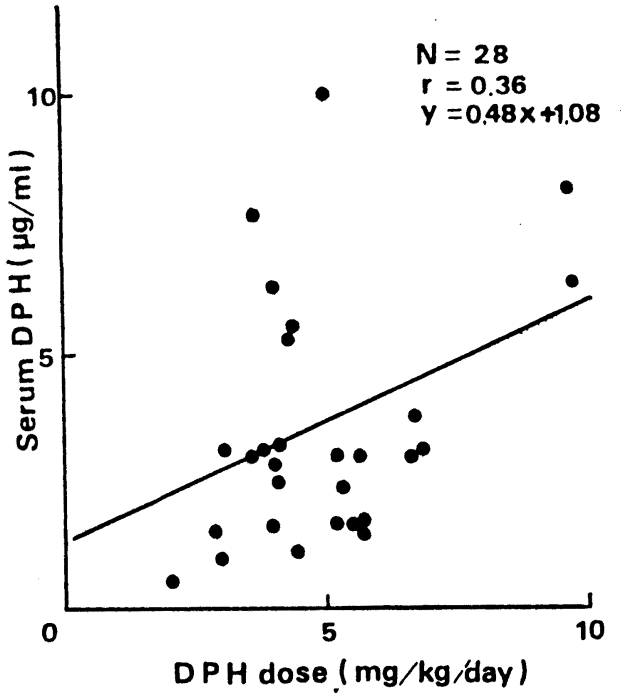

Fig. 2-2. Serum Levels of DPH with PM Treatment

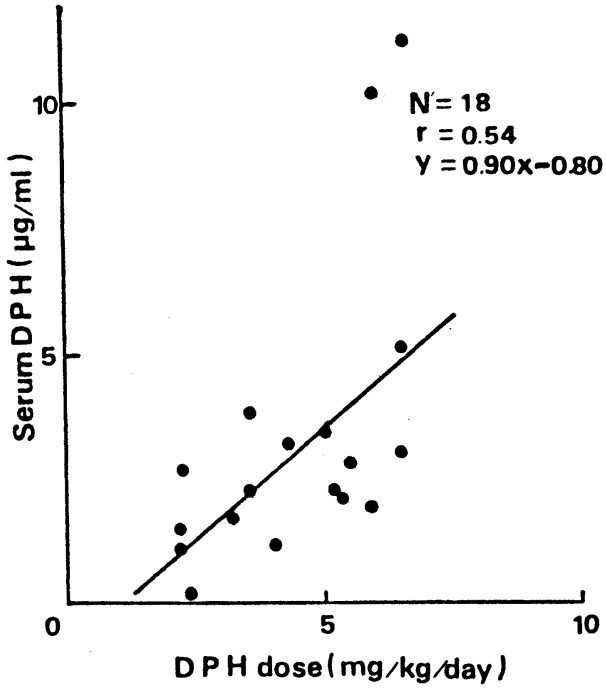

Fig. 2-4. Serum Levels of DPH without PB and PM Treatment 
のものが 2 例みられたが, 他の 16 例については $5 \mu \mathrm{g} / \mathrm{ml}$ 以下であった。

\section{CBZ の併用と非併用時における DPH 血中浱度} DPH の血中濃度に CBZ の有無がどのように影響す るのかを検副したものを Fig. 3 に示した.

Fig.3-1 はCBZ を併用した群で 104例のものであり， Fig. 3-2 は非併用時における 23例の DPH の血中濃度 を示したものである．両者を比較すると，併用時の場合 回帰直線は $\mathrm{Y}=0.74 \mathrm{X}-0.25$ 之高く, 非併用時では $\mathrm{Y}=$ $0.24 \mathrm{X}+1.32$ と低く, 相関係数 $\mathrm{r}=0.21$ と低い。

以上: $\mathrm{PB}, \mathrm{PM}, \mathrm{CBZ}$ の併用, 非併用時における $\mathrm{DPH}$

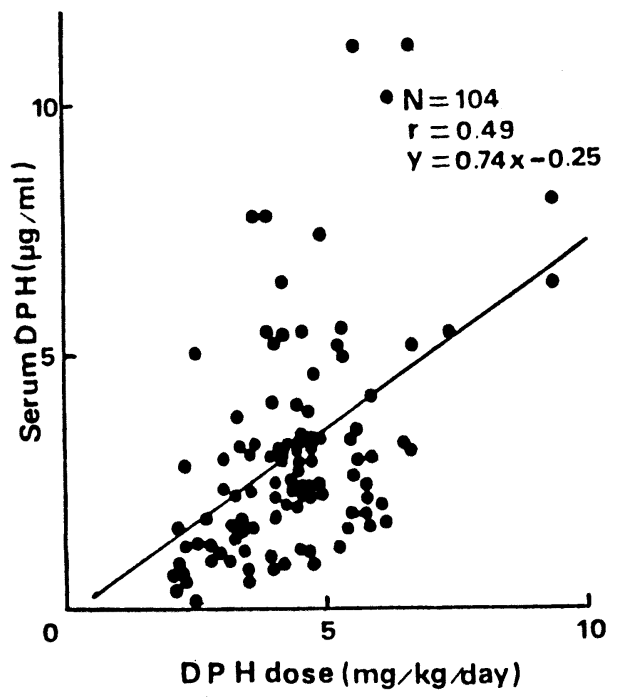

の投与量と血中濃度の関係を Table 2 に示した.

6. ACAの併用ならびに非併用時における DPH 血中 灌度

DPH の投与量と血中濃度に ACA の有無がどのよう。 に影響するのかをみたものが Fig. 4 で, Fig. 4-1 は ACA 併用例, Fig. 4-2 は非併用例で, 前者と後者の差 違は見られなかった。

7. SUL の併用ならびに非併用時における DPH 血中 灌度

Fig. 5-1 は SUL 併用時における DPH血 中濃度を 示したもので，Fig. 5-2の非併用時と比較すると相関

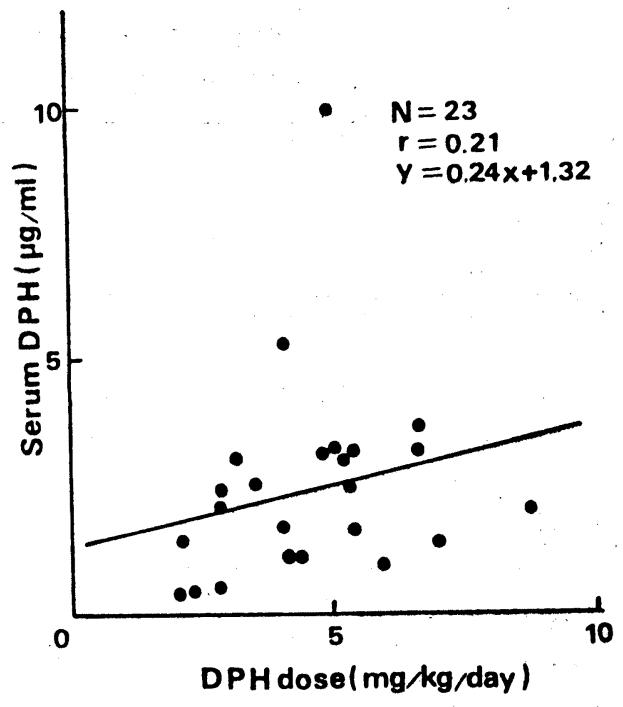

Fig. 3-1. Serum Levels of DPH with CBZ Treatment Fig. 3-2. Serum Levels of DPH without CBZ Treatment
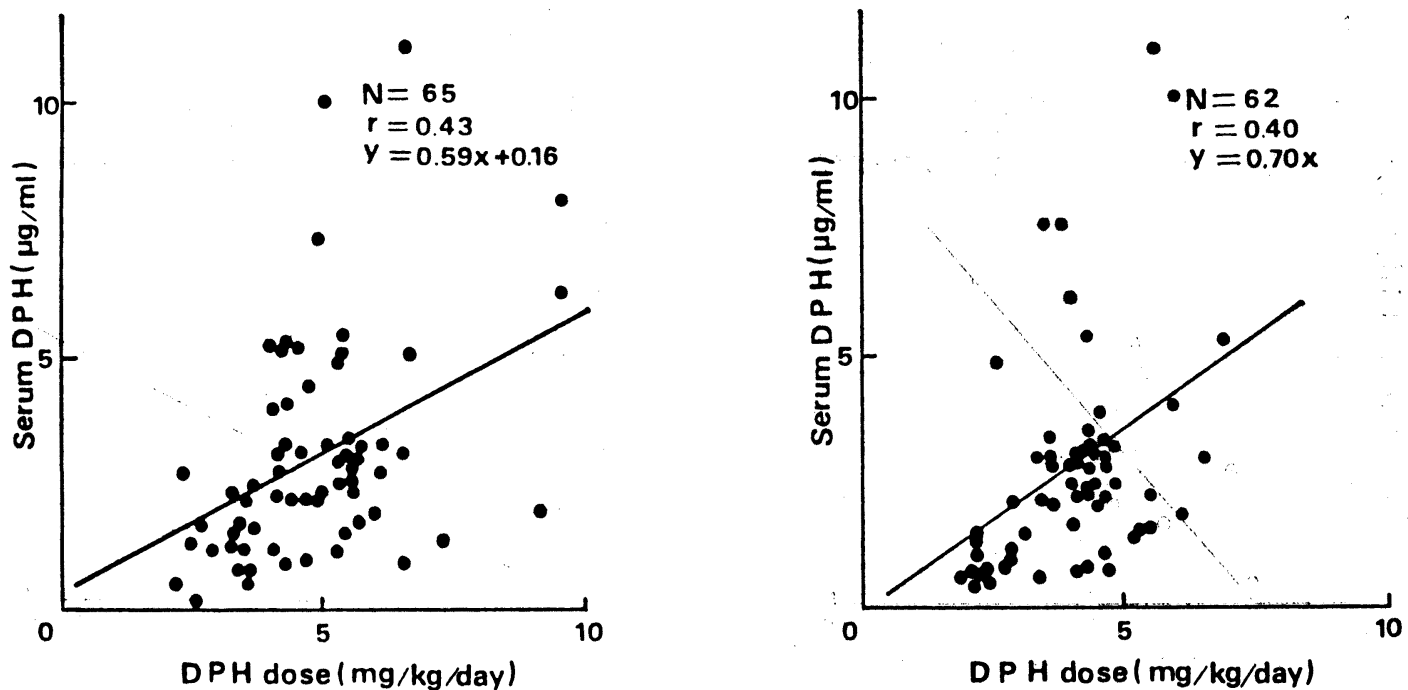

Fig. 4-1. Serum Levels of DPH with ACA Treatment Fig. 4-2. Serum Levels of DPH without ACA Treatment 
Table 2. Serum DPH Levels Data

\begin{tabular}{|c|c|c|c|c|c|}
\hline \multirow{2}{*}{ Groups } & \multirow{2}{*}{$\mathbf{N}$} & $D(m g / k g / t a y)$ & \multirow{2}{*}{$\frac{L(\mu \mathrm{g} / \mathrm{ml})}{\bar{X} \pm S D}$} & \multirow{2}{*}{$\begin{array}{c}\text { Correlation } \\
\text { coefficient }\end{array}$} & \multirow{2}{*}{ Slope } \\
\hline & & $\bar{x} \pm S D$ & & & \\
\hline \multicolumn{5}{|l|}{ DPH } & 0.50 \\
\hline with PM & 28 & $4.9 \pm 1.8$ & $3.4 \pm 2.4$ & 0.36 & 0.48 \\
\hline with PB+PM & 31 & $3.4 \pm 0.9$ & $2.6 \pm 1.8$ & 0.57 & 1.12 \\
\hline without PB,PM & 18 & $4.5 \pm 1.7$ & $3.2 \pm 2.9$ & 0.54 & 0.90 \\
\hline \multicolumn{6}{|l|}{ DPH } \\
\hline with $\mathrm{CBZ}$ & 104 & $4.3 \pm 1.4$ & $2.9 \pm 2.2$ & 0.49 & 0.74 \\
\hline without CBZ & 23 & $4.6 \pm 1.8$ & $2.4 \pm 2.0$ & 0.21 & 0.24 \\
\hline
\end{tabular}

係数 $\mathrm{r}=0.55$ で, 非併用時より回㷌直線とも $\mathrm{Y}=1.28$ $\mathrm{X}-2.42$ と高値を示した。

\section{CZPの併用ならびに非併用時における DPH 血中}

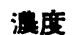

Fig. 6-1 は CZP 併用時における DPH 血中濃度で ある. 相関が 0.25 と低く，傾きも0.16 と低く，Fig. 6 -2 の非併用時に比べると, 投与量に対し 血中濃度が低 い傾向を示した。

以上 ACA，SUL，CZP の併用，非併用時における DPH の投与量と血中濃度の関係を Table 3 に示した.

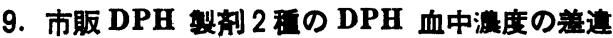

Fig. 7 は市販AおよびBの DPH 製剤 2 種の原末を,

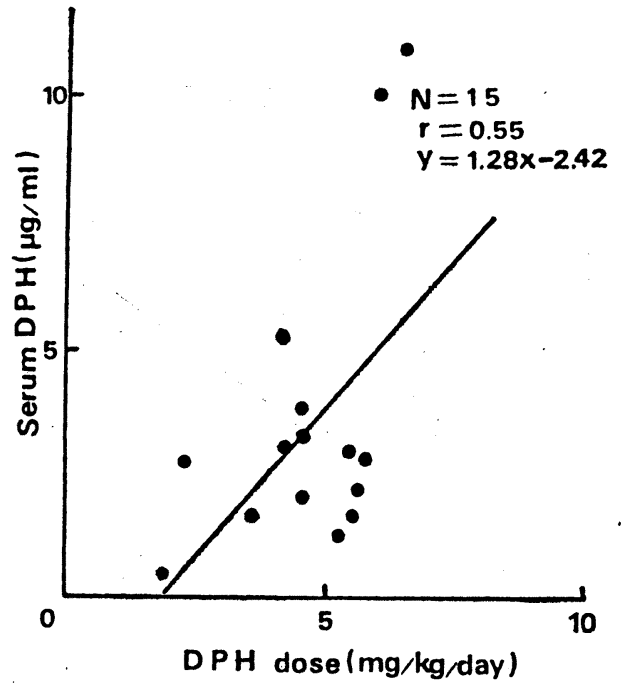

Fig. 5-1. Serum Levels of DPH with SUL Treatment
同一の投与量で服用させた時の DPH 血中濃度の変化を 示したもので，全体で 28例中，上昇例が 24例 (86\%) で，顕著な例としては血中濃度が1.4から 30，1.6から 17.8 ，急激な血中濃度の上昇が見られた例もある。こ のことは現在のところ十分解明されていないが，製剤間 により明らかな差違があり，DPH の投与量と血中濃度 の関係が重要であることを示す (Table 4).

\section{稳括ならびに考腺}

以上の結果を総括すると，DPH の血中濃度は Fig. 1 に示すように投与量に比べ低血中濃度の症例が多く, こ れは Buchthal2) らが有効治療濃度としている 10～20 $\mu \mathrm{g}$

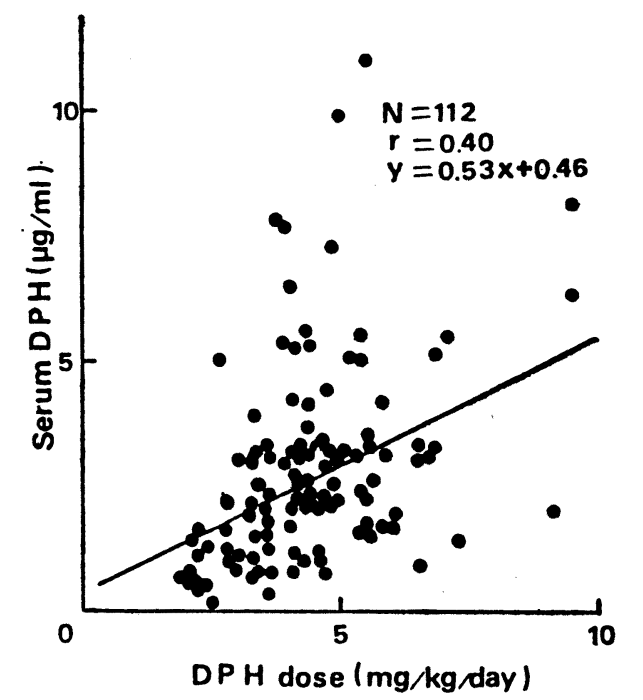

Fig. 5-2. Serum Levels of DPH without SUL Treatment 

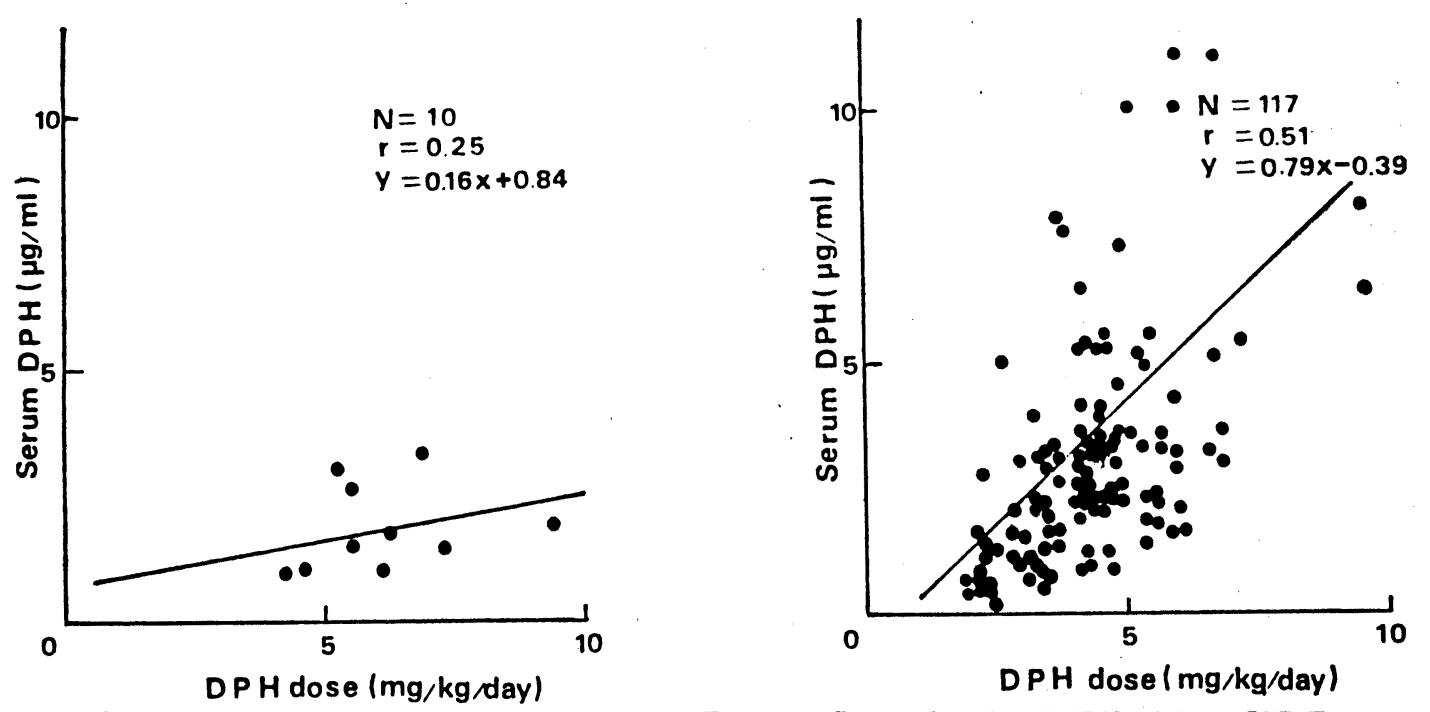

Fig. 6-1. Serum Levels of DPH with CZP Treatment Fig. 6-2. Serum Levels of DPH without CZP Treatment

Table 3. Serum DPH Levels Data

\begin{tabular}{|c|c|c|c|c|c|}
\hline \multirow{2}{*}{ Groups } & \multirow{2}{*}{$N$} & \multirow{2}{*}{\begin{tabular}{|l|} 
(mg/kgetary \\
$\bar{X} \pm S D$
\end{tabular}} & \multirow{2}{*}{$\frac{L(\mu g / m l)}{\bar{X} \pm S D}$} & \multirow{2}{*}{$\begin{array}{c}\text { Correlation } \\
\text { coefficient }\end{array}$} & \multirow{2}{*}{ Slope } \\
\hline & & & & & \\
\hline $\begin{array}{l}\text { DPH } \\
\text { with } A C A\end{array}$ & 65 & $4.8 \pm 1.6$ & $3.0 \pm 2.2$ & 0.43 & 0.59 \\
\hline without $A C A$ & 62 & $3.9 \pm 1.2$ & $2.7 \pm 2.2$ & 0.40 & 0.70 \\
\hline \multicolumn{6}{|l|}{ DPH } \\
\hline without SUL & 112 & $4.3 \pm 1.5$ & $2.8 \pm 2.0$ & 0.40 & 0.53 \\
\hline \multicolumn{6}{|l|}{ DPH } \\
\hline with & 10 & $6.0 \pm 1.4$ & $1.8 \pm 0.9$ & 0.25 & 0.16 \\
\hline without CZP & 117 & $4.2 \pm 1.4$ & $2.9 \pm 2.2$ & 0.51 & 0.79 \\
\hline
\end{tabular}

* Significant difference $(p<0.05)$

Table 4. Effect of Two Products to DPH Serum Level

\begin{tabular}{l|c|c|c}
\hline G roups & $N$ & $D(m g / k g / d a y)$ & $L(\mu g / m I)$ \\
\cline { 3 - 4 } & $\bar{X} \pm S D$ & $\bar{X} \pm S D$ \\
\hline $\begin{array}{c}\text { DPH-A } \\
\text { Lot.No. } \\
\text { WD252 }\end{array}$ & 28 & $3.9 \pm 1.4$ & $1.8 \pm 1.9$ \\
$\begin{array}{c}\text { DPH-B } \\
\text { Lot.No. } \\
\text { LPO03LO }\end{array}$ & 28 & $3.9 \pm 1.4$ & $5.6 \pm 6.7^{*}$ \\
\hline
\end{tabular}

* Significant difference $(p<0.01)$ 
$/ \mathrm{ml}$ の範囲にある症例はわずか 4 例にすぎなかった。これ は渡辺ら ${ }^{3)}$ の報告と類似しており，わが国における他の多 くの報告 ${ }^{3-5)}$ 飞おいても一般に投与量に比べ血中濃度が低いよ うである。つぎに単独ならびに 2 種併用例と比較すると，多 剤併用例では Tablel 1 亿示すように有意の差 $(\mathrm{P}<0.05)$ で 血中㳻度の上萁が認められた。しかし著者らのデータにおい ては多剂併用例中，PB が $74 \%$ 併用されており，PB が楽物 代謝酵素の誘導にもとづく代謝を促進する結果, DPH の血中 濃度が上昇しにくいといら報告 ${ }^{3,5,6)}$ とは矛盾する結果となっ ている.

つぎに.DPH`の多剤併用 127例において，PB，PM， CBZ, ACA， SUL， CZP の DPH 血中濃度への影響を, 各併用群と 非併用群に和いて比較検討した. 田名部》は DPH の血中濃 度が PB を併用すると血中濃度の低下がみられたと報告して いる. 一方西原ら ${ }^{8)}$ とると， DPH 単独と PBを併用してい る群の血中 DPH 濃度には差が認められなかったと報告して いる.著者らの結果では Table 2 に示すように, PBおよび PM.飞执いて投与量と血中濃度で有意の差は認められなかっ た. しかし Fig. 2-3 の PB と PMの同時併用群において, この両者の併用により PB の血中濃度が容易に上昇するとい 万点から，DPHの投与量が $5 \mathrm{mg} / \mathrm{kg}$ 以上の 症例がなく断定は できないが，低投与量であるということは興味深い。つぎに CBZ については，併用することにより DPH の血中濃度を上 げるという報告9,10) や反対に下げるといら報告 ${ }^{11)}$ があるが， 著者らのデータにおいては Table 2 に示すように有意の差は みられなかったが，非併用群において相関性がみられず回㷌 直線も $\mathrm{Y}=0.24 \mathrm{X}+1.32$ 之低い值が得られた。

つぎに ACA については併用することにより，DPH の血中濃度を上げるとの報告") があるが, Table 3 に示 すように有意の差はみられなかった，SUL についても 併用することにより DPH の 血中濃度を上げるとの報 告9) があるが, Table 3 に示すように有意の美はみられ なかった。

つぎに CZP については，Fig. 6 に示すように，併 用群において相関が $\mathrm{r}=0.25$ ときわめて低くまた傾き む 0.16であり, これは Edwardsら ${ }^{12)}$ の報告と一致し ており, Table 3 亿示すように有意の差 $(P<0.05)$ で血 中濃度の抑制が認められた. 最後に Fig. 1 亿示すよう にDPH の投与量に比べ血中濃度が低く, その原因とし て Biopharmaceutical factors と関係があると考えら れたので, 粒子径に着目して検討した。すなわち，2 種 の市販の DPH原末を, 同一患者 $(\mathrm{N}=28)$, 同投与量で 比較検討をした。著者らの用いた DPH 原末は，DPHAが平均粒子サイズ $108 \mu \mathrm{m}, \mathrm{DPH}-\mathrm{B}$ が $55 \mu \mathrm{m}$ である.

. Fig. 7 にみられるように DPH の血中濃度の上昇, Table 4 に示すように平均血中濃度が 3 倍となり有意の 差 $(\mathrm{P}<0.01)$ で血中濃度の上昇が認められた.

DPH の剂形の相違による DPH 血中濃度のちがいに ついてはいくつかの報告 ${ }^{13,14)}$ があり, Lund ${ }^{15)}$ は DPH の $\mathrm{Na}$ 塩は遊離酸型より腸管からの吸収効率がよく，こ れは Na 塩が消化管内でより小粒子になるためであろう と報告している.以来，わが国においてすいくつかの研 究報告18-18) がなされている.なかでも北原16) は 200 〜270号 mesh 通過のフェニトイン散は大粒子のフェ $=$ トイン散に比へ S/D 比が高く，腸管吸収がよく，また 約 70\%が 60〜100mesh 通過のフェニトイン散はS/D比 が低く，吸収がより不良であることを報告している。一 方，新熊 ${ }^{17)}$ は，DPH-Na, DPH原末（平均粒子サイズ $; 90 \mu \mathrm{m}), \mathrm{DPH}$ 微末 $(4.1 \mu \mathrm{m})$ の 3 製剤において溶出試 験およびヒトにおける血中濃度において比較した。その 結果, $\mathrm{Na}$ 塩が血中濃度が最も高く, ついで微末で, そ れぞれ原末の 4.5 倍，2.3倍であったと報告している. 
以上の事実から，DPH 原末の稙子径によりその吸収 が大きく左右され，血中濃度への影埄がみられることは きわめて柰要である。このことは DPH に限ったことで はないが，浩旗域と小南域の接近している薬剂, たと兄

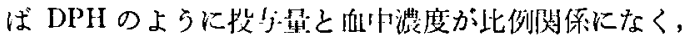

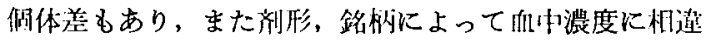

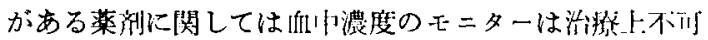

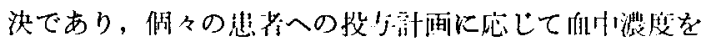
チェックすることが必票であると孝えられる。

\section{交塥}

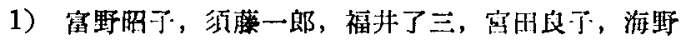
勝是: 病院菜学, 5, 141 (1979).

2) F. Buchthal, O. Svensmark, and P. J. Schiller : Arch. Neurol., 2, 624 (1960).

3）湾辺冒䘠, 久山干衣, 横山茂生, 久保信介, 岩非

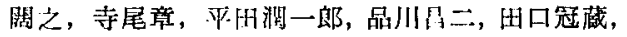

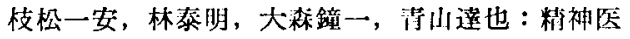
学, 19, 972 (1977).

4）宾本㑆治：小児科䜿床，29，514 (1976).

5）阔中倍也, 名和田宏, 井沢正博, 橋本宣雄, 杉山 弘行, 斎藤你也: 脳神释, 27, 583 (1975).

6）清野昌一，管本㑆治：粉神医学，20（5)，489
(1978).

7) 田名部系之：脳之発達，7，114(1975).

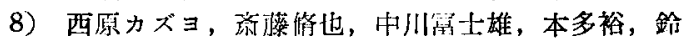
木徳治：医学のむりる，103，810 (1977).

9）藤非一貫，竹下砳三，渡辺美簤子：脳と発達，6， 456 (1974).

10）二浦史楌：臨床精神医学，7，567 (1978).

11）三浦表楼，皆川公夫，八木二郎，加藤誶，金子次 雄：脳と発達，8６，455 (1976).

12) V. E. Edwards and M. J. Eadie : Proc. Aust. Assoc. Neurol., 10, 61 (1973).

13) S. Chakrabarti, F. M. Belpaire : J. Pharm. Pharmac., 30, 330 (1978).

14) P. J. Neuvonen, P.J. Pentikä inen, and S. M. Elfving : Int. Clin. Pharmacol. Biopharm., 15, 18 (1977).

15) L. Lund : Eur. J. Clin. Pharmacol., 7, 119 (1974).

16）北原久枝：脳と発達，11（5)，406(1979).

17）新熊伝治, 橋本筆, 山中要, 守田嘉男, 水野亘塨 : 薬剂学, 39 (3), (1979).

18）高橋系一, 本田利伝, 高橋寛, 大塚親哉, 佈藤晹 了: : 脳と発達, 11 (6), 510 (1979).

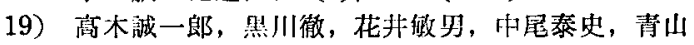
做信：脳と発達, 11，548（1979）.

\section{口成分}

レベニン1g中 次の成分を命行しています。

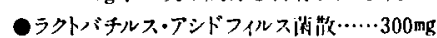

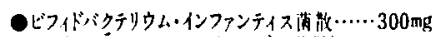
(ラクトバチルス・ビフィズフ消花)

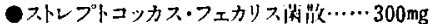

効能・新果

䋓消消数 $1.2 \times 10^{7}$ 湖以上 $/ \mathrm{g}$

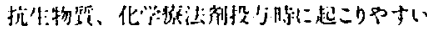

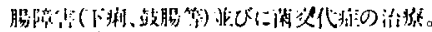

\section{口用法・用量}

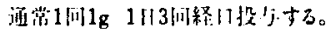

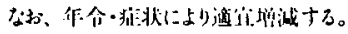

\section{西资}

$1 \mathrm{~kg} \cdot 5 \mathrm{~kg}$ (バラ)

$1 \mathrm{~g} \times 1200$ 包(ヒートシール)包㘳コード: (W LNP Ig

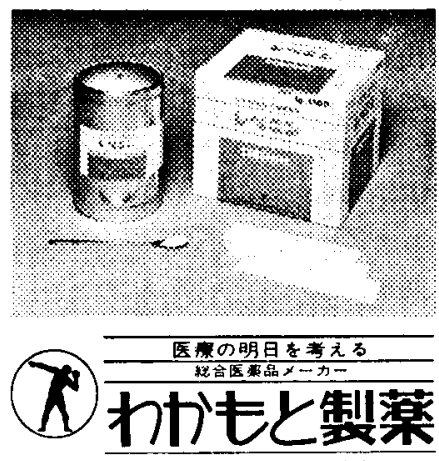

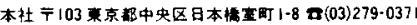

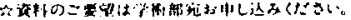

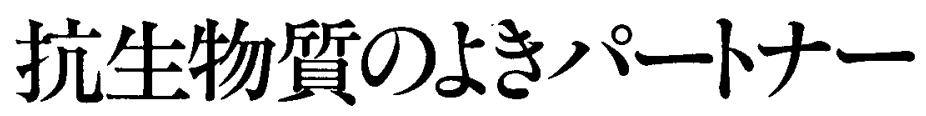

抗生物質耐性 乳酸菌製剂

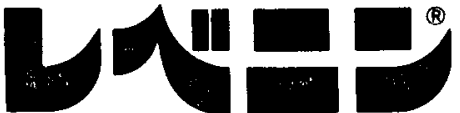

LEBENIN

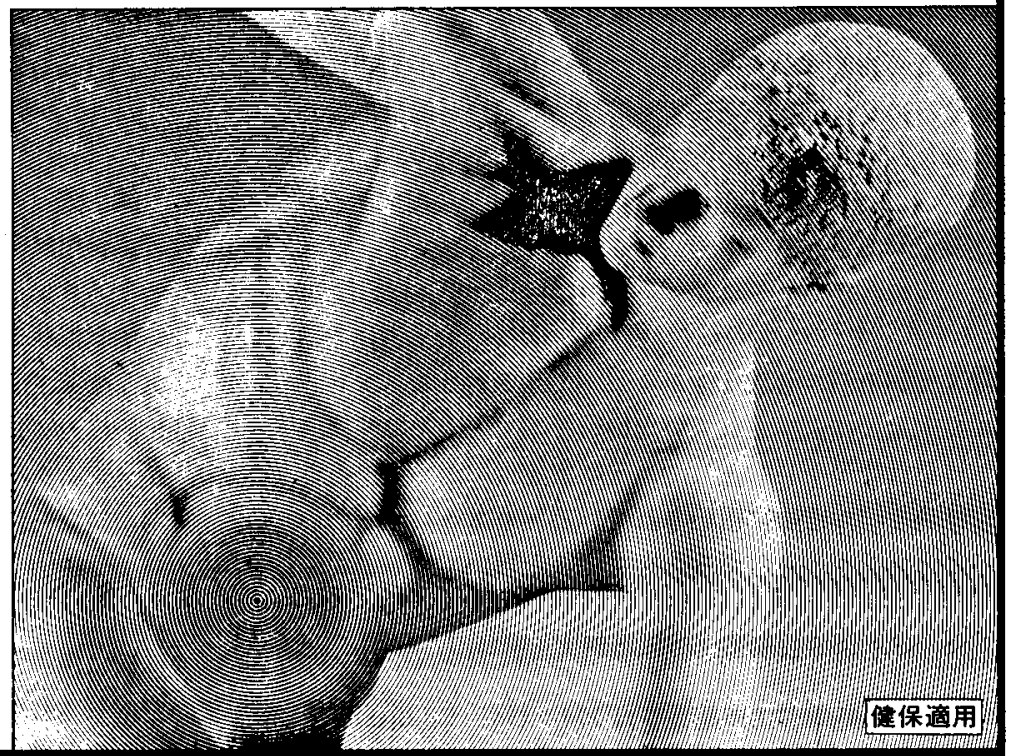

